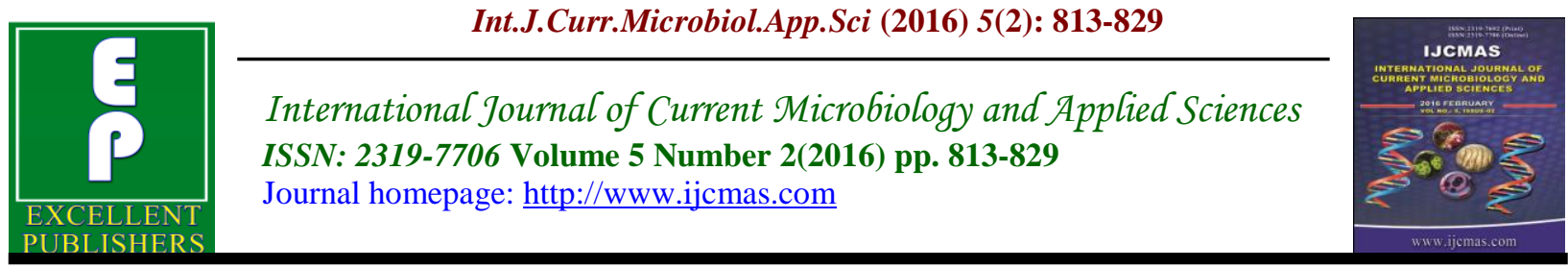

Original Research Article

doi: http://dx.doi.org/10.20546/ijcmas.2016.502.093

\title{
Ethnobotany, Phytochemical Screening and Toxicity Risk of Cleome gynandra and Cleome viscosa, two traditional leafy vegetables consumed in Benin
}

\author{
E. Ahouansinkpo', J. Atanasso ${ }^{1}$, A. Dansi ${ }^{2}$, A. Adjatin ${ }^{2}$, Orobiyi Azize ${ }^{2}$ and A. Sanni ${ }^{3}$ \\ ${ }^{1}$ Faculty of Agricultural Sciences, University of Abomey-Calavi, 01 BP 526, Calavi, Benin \\ ${ }^{2}$ Laboratory of Biotechnology, Genetic Resources and Plant and Animal Breeding (BIORAVE), \\ Polytechnic University of Abomey (UPA), BP 14, Dassa, Benin \\ ${ }^{3}$ Laboratory of Biochemistry and Molecular Biology, Faculty of Sciences and Technology \\ (FAST), University of Abomey-Calavi (UAC), Benin \\ *Corresponding author
}

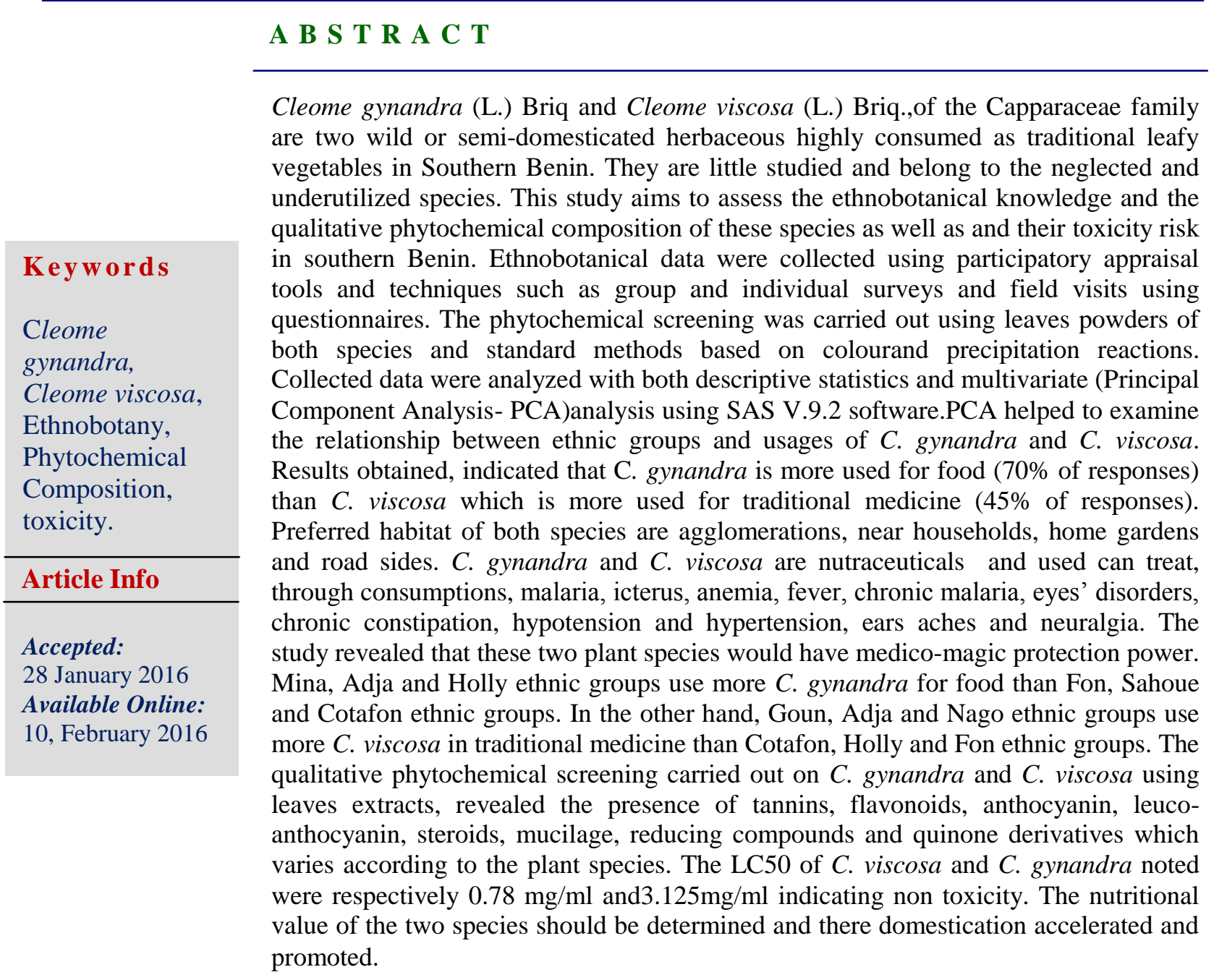




\section{Introduction}

Many plants are used by local communities to satisfy their food needs, nutrition and health and constitute a source of additional income and employment (Sandhya et al., 2006; FAO, 2012; Visweswari et al., 2013).Generally, plants produce metabolites that confers to them, many medicinal virtues that are at the basis of their utilization by people (Zwenger and Basu, 2008; Visweswari et al., 2013; Adjatin et al., 2013). Among them, certain are consumed as traditional leafy vegetables (LFTs) which play an important role in food, nutrition and health of populations because of their availability and richness in nutrients. In Benin, Dansi et al., (2012) reported 187 plant species consumed as leafy vegetables among which Cleome gynandra L. (Briq.) and Cleome viscosa L. (Briq.) classified in the group of theso-called neglected and underutilized species of high priority on which further study must be performed. In Asia and Africa, leaves and seeds are used to treat different infections including fever, anemia, rheumatism and headaches (Grubben et al., 2004; Jane et al., 2012).

In Benin, Cleome gynandraL. (Briq.) and Cleome viscosa L. are wild or semidomesticated species (Vodouhe et al., 2012). Contrary to other LFTssuch as Crassocephalum rubens and Crassocephalum crepidioides that are well studied (Adjatin et al., 2012), few study were carried out on these two species. In order to fill this gap and facilitate the valorization of their genetic resources, it is necessary to conduct a thorough study ontheir ethnobotany. Moreover, it is important to do a comparative phytochemical evaluation of $C$. gynandra and $C$. viscosa to rightly appreciate their increased use in the prevention or treatment of certain illness. Accurate knowledge of the habitat, ecological requirements and usefulness of a plant species is the cornerstone of any program focusing on the conservation and domestication of this species. These studies are necessary for a better knowledge of the species in order to valorize, promote and conserve them forthe benefit of rural populations (Dansi et al., 2008).

The general objective of this study is to contribute to food security and health of the population in Benin through a better knowledge of Cleome gynandra and Cleome viscosa for their valorization and sustainable use. Specifically, the study aims to document the ethnobotanical knowledge of Cleome gynandra and Cleome viscosain southern Benin; and to determine the qualitative phytochemical compositions of both species in relation with their medicinal use assess the toxicity of the leaves of the two species

\section{Materials and Methods}

\section{Study Area}

Benin is Located in West Africa between Nigeria and Ghana., Southern Benin (Figure 1) grouping the administrative departments of Mono, Couffo, Atlantique, Littoral, Oueme and Plateau constitutes the study area. Southern Benin is inhabited by about 9.9 millions of habitants (INSAE, 2013) belonging to 14 (Adja, Aizo, Cotafon, Fon, Goun, Holly, Mina, Nago, Peda Sahouè, Tori, Watchi, Xwla, Yoruba) ethnic groups (Akoègninou et al., 2006). The climate is sub-equatorial and the average annual rainfall varies from $900-1500 \mathrm{~mm}$ per year (Akoègninou et al., 2006). The average annual temperature is $26.5^{\circ} \mathrm{C}$ and the relative humidity is, on average, $75 \%$ per year (Akoègninou et al., 2006). The soil is ferruginous, lateritic, vertisols or 
hydromorphic soils (Akoègninou et al., 2006). The vegetation is constituted of mosaic of forest and savannah (Akoègninou et al., 2006).

\section{Site Selection and Data Collection}

Based on results of research carried out by Dansi et al., (2008), Codjia et al., (2009) and Akoègninou et al., (2006), 9 villages (Table 1, Figure 1) were selected for the study (Figure 1). Preliminary surveys were carried out in order to determine the size (n) of the sample (interviewees) to be considered for the survey following Dagnelie (1998) formula which is:

$$
\mathrm{n}=\frac{\mathrm{U}_{1-\alpha / 2}^{2} \times \mathrm{p}(1-\mathrm{p})}{\mathrm{d}^{2}}
$$

$\mathrm{n}=$ sample size; $\mathrm{U} 1-\alpha / 2$ is the value of the normal variable reduced for a probability value; $\alpha=0.05$; U1- $\alpha / 2=1.96$; $\mathrm{p}$ is the proportion of individuals who know the species ( $\mathrm{p}$ varies from a locality to another); $\mathrm{d}$ is the marginal error set at 0.08. In total 260 people were surveyed in nine villages. Data collected from individual surveys were related to the knowledge or not of $C$. gynandra and $C$. viscosa, the vernacular names and their meanings, the habitats of the species and the farmers' perception of their the abundance in these habitats, the organs harvested for use, the use patterns (food, medicinal and medico-magical) of the species, the mode of utilisation and the domestication level according to the model proposed by Vodouhe et al., (2012) that defines six levels of domestication: Level 0: wildlife species; Level 1: Species just spared in the fields during field works; Level 2: Species spared in the fields but benefits from some care for its growth; Level 3: Species transplanted from the nature to the cultivated fields or home gardens; Level 4: Species well cultivated and reproduced; Level 5: Species cultivated with some selection activities; Level 6: Pests and diseases are knownas well as their means of control.

\section{Phytochemical Analysis}

Samples (stems and leaves) of the plant (Cleome gynandra and Cleome viscosa) were obtained from the germplasm maintained at the Faculty of Science and Technology of Dassa (FAST Dassa) in Benin. They were washed thoroughly under running tap water followed by sterile distilled water, cut into smaller pieces and dried under shade during for 9 days. The dried plant parts were ground using electric blending machine and the powdery samples obtained were sieved using two sieves of $0.2 \mathrm{~mm}$ (mesh size) and stored in air tight sterile containers until needed.

Qualitative phytochemical screening was carried out on the powdery samples, after extraction with aqueous solvent, using the standardly employed precipitation and coloration reactions as described by Houghton and Raman (1998) and Dougnon et al., (2013). Major secondary metabolites essayed and the methods used were as follow: Alkaloids (Mayer's test), Quinone derivatives (born-trager reaction), Cathetic tannins (stiasny test), Gallic tannins (ferric chloride test after saturation with sodium acetate), Flavonoids (shinoda test and magnesium powder), Cyanogenic derivatives (picric acid test), Triterpenoids (acetic acid test + mixture of acetic an hydride and sulfuric acid), Steroids (kedde reaction), Saponins (test index foam), Cardiac glycosides (Raymond Marthoud reaction), Anthocyanins (test with hydrochloric acid and ammonia diluted to half), Leucoanthocyanes (shinoda test), Mucilage (test of absolute alcohol), Reducing compounds (test with fehling's solution), Coumarins (test with ether 
andammonia), Free anthracene derivatives (test with chloroform and ammonia), Combined anthracene derivatives (test with chloroform and ammonia).

\section{Brine Shrimp Lethality Assay}

The cytotoxic activity of the extracts of the two species was evaluated using Brine shrimp lethality bioassay. Brine shrimp (Artemiasalina Leach) also known as sea monkey are marine invertebrates of about $1 \mathrm{~mm}$ in size. The test is basedon the survival of shrimp larvae in sea water in the presence of the test solution. Its interest lies in understanding the possible side effects that would result from consumption of leaves of vegetable Cleome on the body. A solution was prepared by moderate heating for 20minutes, the mixture of 1gof powdered leaves of Cleome gynandra or Cleome viscose in $20 \mathrm{ml}$ of distilled water following Dougnon et al., (2013). The concentration of $50 \mathrm{mg} / \mathrm{ml}$ was obtained and arrange often successive dilutions $(49 \mu \mathrm{g} / \mathrm{ml}, 98 \mu \mathrm{g} / \mathrm{ml}, 195 \mu \mathrm{g} / \mathrm{ml}, 391$ $\mu \mathrm{g} / \mathrm{ml}, \quad 781 \mu \mathrm{g} / \mathrm{ml}, 1582 \mu \mathrm{g} / \mathrm{ml}, 3125$ $\mu \mathrm{g} / \mathrm{ml}, 6250 \mu \mathrm{g} / \mathrm{ml}, 12500 \mu \mathrm{g} / \mathrm{ml}, 25000$ $\mu \mathrm{g} / \mathrm{ml}$ ) were made with seawater from decoction. Eggs of A.salina were grown in an Erlenmeyer containing seawater taken from the Atlantic Ocean and filtered before use. The mixture (eggs and sea water) was left under stirring for 48 hours. Meanwhile, the eggs were hatched to give birth to young larvae (nauplii). Using a pipette, a colony of 16 live larvae was placed in contact with the series of solutions of graded concentrations of decoction of Cleome gynandra and Cleome viscosa. These solutions and the controls containing no extract of the Vegetable Cleome were left stirring and read after 24 hoursof incubation. The total death and percentage mortality (death) at each dose level and control were determined. To assess the degree of toxicity of the different species, the LC50and toxicity corresponding table (Table 2) was used following Agbaire et al., (2013) and Dougnon et al., (2013).

\section{Data Analysis}

Data collected were analyzed by both descriptive statistic and multivariate analysis and the results are presented in the form of table and figure. The index of Cultural importance (CIs) of each species was calculated by the formula of Tardio and Pardo-de-Santayana (2008) indicating the most important uses of the species. SAS V 9.2 software was used to perform PCA (Principal component Analysis) in order to assess the relationship between the different uses and the ethnic groups surveyed.

For each extract or sample the lethal concentration that causes 50\% death (LC50) was calculated at $95 \%$ confidence interval by linear regression analysis and also by using the probit analysis method following Ullah et al., (2013). A regression line equation was derived for each extract with the mortality data obtained and, it was then used to calculate the LC50 value. The detailed mathematical steps used to derive the regression line equation are reported in the literature (Hubert, 1980; Vincent, 2012).

\section{Results and Discussion}

\section{Ethnobotanical Investigation}

For each species considered, the index of Cultural Importance (CI) was calculated (Table 3) to appreciate the relative importance of each species for the local populations. The results obtained (Table.3) indicate that the cultural importance of $C$. gynandrais greater than the one of $C$. viscosa. $C$. gynandra has more food importance $($ CIUA $=0.7)$ while $C$. viscose shows greater medicinal importance $($ CIUM $=0.45)$. Indeed, $70 \%$ of the surveyed population use $C$. gynandra for food against 
$38 \%$ who use it for traditional medicine and only $6 \%$ for medico-magic matter. In contrast, $45 \%$ of this same population use C. viscosa for traditional medicine, $2 \%$ use it for food and $4 \%$ use it for medico-magic.

The vernacular names of each species vary according to the ethnic groups surveyed (Table 5). Across all ethnic groups $C$. gynandra is considered as "female" Cleome or domesticated Cleome while $C$. viscosa is called "male" or wild Cleome. However, the female and male terminologies are not linked to the sexuality of the species. The study revealed that $C$. gynandra and $C$. viscosa are used to prevent or cure 20 illnesses (Table 5). The leaves are the most organ used for the different treatments.

The medico-magical use of $C$. gynandra and C. viscosa is low. Sauce of C. gynandra or $C$. viscose eaten regularly would give longevity while their leaves harvested, dried and burned as incense move away evil spirits. $C$. viscosa is also a luck plant. The leaves crushed with perfume and passed on the body would attract happiness.

In terms of habitat, $C$. gynandra and $C$. viscose were found in agglomeration, homes and roadsides as well as in fields and in fallows. In their preferred habitats, their domestication levels vary from one village to another. $C$. viscosa is at level 0 of domestication in all villages except Okebodé and Koutongbé where it was found respectively at domestication levels 3 and 1 (Figure 2). In the villages Issaba, Okebodé, Niaouli and Zohoudji, C. gynandra was found at domestication levels 0 and 3 with level 3 predominant at Issaba and Zohoudji. In Ahouango and Koutogbé villages, the species is still in the wild (level 0 and 1). In the market garden of Houéyiho and in the Adromè-Kpovidji and Ahouamè, domestication of $C$. gynandra is advanced (level 4).

Harvest method influences the availability and conservation of leafy vegetable species (Dansi et al., 2008; Adjatin et al., 2012; Vodouhe et al., 2012). C. Gynandra and C. viscosa were harvested by cutting leaves and rarely by uprooting. They are available in abundance during the rainy season. In the dry season, $C$. viscose becomes scarce but $C$. gynandra remains available in home gardens.

According to the results obtained, four (04) types of habitat are known for $C$. gynandra and $C$. viscosa. Similar results were reported by Akoègninou et al., (2006), Codjia et al (2009), Soro et al., (2012) and Bâ (2013). The low distribution of $C$. gynandra in the fields and in the fallows in southern Benin can be explained by the demographic growth but also by urbanization. Population growth causes devastating cultural practices (Adegbola et al., 2002; Goussanou and al. 2011) while increasing urbanization leads to loss of habitats and plant resources. This is confirmed by the reports of Kateb (2004) and Djègo et al., (2011) according to which urbanization is the main reason of the plant genetic resources erosion raised by the traditional healers and farmers. Our results are also consistent with those obtained by Sinsin et al., (2009) indicating that plant resources are subject to high human pressures through agriculture, transhumance, pruning, bush fires, collection of NTFPs and construction of houses.

In southern Benin, $C$. gynandra has a food and cultural importance. This confirms the work of Dansi et al., (2008) which showed that $C$. gynandra is consumed as a leafy vegetable in Benin and help understanding its advanced domestication level. C. gynandra is already transplanted from the wild status to fields and home gardens. In the study area farmers reported that the consumption of $C$. gynandra in sauce is a guarantee of a good health and longevity and the plant is therefore seen as a nutraceuticals leafy vegetable. The longevity aspect rhymes with the proverb " $C$. gynandra never dies without having white hair." This adage confirms the nickname "the whitehaired man" given to this plant by Senegalese as reported by Bâ (2013). 
Unlike $C$ gynandra, $C$. viscosa has mostly medicinal importance. This can be explained by its potential to cure diseases such as malaria, jaundice whose consequences are feared by the populations. Akoegninou et al., (2006) and Bâ (2013) reported that C. viscosa is indicated against eye disorders, chronic constipation, hypo / hypertension and neuralgia.

\section{Relationship between ethnic groups and uses of $C$. gynandra and $C$. viscose}

To examine the relationship between ethnic groups and uses of the species, a Principal Component Analysis (PCA) was performed by considering the ethnic groups as individuals and the three types of use (food, medicinal use, medico-magic use) as variables. In $C$. gynandra and $C$. viscose species, analyses revealed that the first two axes are highly significant and account for $78.02 \%$ and $72.22 \%$ of the available information respectively.

With C. gynandra the correlations between the main components and these variables (Table 6) show that UA, UM and UMM are better represented on axis 1 while UA is the best shown in the axis 2. On axis 1 of the PCA, the Fon, Sahouè, Cotafon, Holly and Aizoethnic groups located at the positive side of the axis are clearly opposed to Goun, Nago, Mina and Adja ethnic groups located at the negative side of the axis (Figure 4). The first ethnic group uses more $C$. gynandra for medicine and medico-magic matters than Goun, Nago, Mina and Adja ethnic groups which use $C$. gynandra only for food. Considering the axis 2, the ethnic groups Mina, Adja, Holly, Cotafon and Sahouè, located at the positive side of the axis and which use more $C$. gynandra for food are clearly opposed to Goun, Nago, and Fon that use $C$. gynandra for medicine and medico-magic problems (Figure. 4). In summary, Fon ethnic group uses $C$. gynandra for its medicinal and medicomagical importance whereas Adjaand Mina ethnic groups use it for its food importance.
The Goun, Nago, Sahouè, Cotafon, Holli and Aizo ethnic groups use $C$. gynandra for its food, medicinal and medico-magical importance.

With $C$. viscosa the first two axes are highly significant and account for $72.22 \%$ of the information related to 3 the variables (UA, UM, UMM) considered. Correlations between these variables and principal components revealed that the AU and UMM variables are better represented on axis 1 . UA is positively correlated $(\mathrm{r}=0.66)$ to that axis while UMM is negatively correlated ( $\mathrm{r}=-0.71)$. UM is best shown on the axis 2 and is positively correlated $(\mathrm{r}=0.83)$ to this axis (Table 7). On the axis 1, the Cotafon, Sahouè, Goun and Adja ethnic groups located at the positive side of the axis are clearly opposed to Nago, Holly, Fon and Mina at the negative side of the axis (Figure 5). This therefore results that Cotafon, Sahouè, Goun and Adjause more $C$. viscose for food and medicine while Nago, Holly, Fon and Minause $C$. viscose for medico-magic problems. On the axis 2, the ethnic Sahouè, Goun, Adja and Nago at the positive side of the axis are clearly opposed to Cotafon, Fon and Holly located on the negative side of the axis (Figure 5).

Therefore, the Sahouè, Goun, Adja and Nago ethnic groups use more $C$. viscosa in traditional therapy (UM and UMM)while Cotafon, Holly and Fon use C. viscosa for food. Aizo and Minaare on the two axes. They moderately use C.viscosa for food, traditional medicine and medico-magic problems.

C. viscosa is more used by Goun, Sahouè and Adja ethnic groups to cure several diseases like fever, chronic malaria and especially to facilitate the first step to the newborn. The low use of $C$. viscosa by Aizo and Mina is explained by their low knowledge of the species. Similar results were obtained by Koura et al., (2011) who showed that Lokpa, Waama and Bariba ethnic groups have a great knowledge of Parkiabiglobosa and use it more for food and medicinal unlike other ethnic 
groups in northern Benin who have a restricted knowledge for this plant.

The study revealed that the ethnic groups Mina, Adja and Holly in one hand and Goun and Nago in the other hand, are particularly involved in the valorization process of $C$. gynandra and $C$. viscosa respectively through domestication practices.

\section{Phytochemical Screening of $C$. gynandra and $C$. viscosa}

Phytochemical analysis revealed that $C$. gynandra and $C$. viscosa have a similar composition (Table 7). Indeed, both species contain tannins, flavonoids, anthocyanins, leuco anthocyanin, steroids, mucilage, reducing compounds, anthracene combined with the $\mathrm{C}$-heteroside derivatives and the quinone. In the two species, saponins, triterpenoids, cardenolides, cyanogenic, coumarins, free anthracene and anthracene combined with O-heteroside are absent. $C$. gynandra contains alkaloids while this is absent withC. viscosa.

The phytochemical analysis showed that $C$. gynandra and $C$. viscose do not contain saponoside, triterpenoid, cadenolides, cyanogenic, coumarins, free anthracene and anthracene combined with O-heterooside. Cyanogenic derivatives and anthracene are real poisoning metabolites (Okwu, 2004) and their absence in the leaves of both species studied, reassures consumers of the risks associated with their use. However, saponinshas expectorant effects in the treatment of respiratory infections $(\mathrm{Okwu}$, 2004). The absence anthracene and cadenolides in $C$. gynandra is in agreement with the report of Ajaiyeoba (2000). The absence of saponins and triterpenoid in $C$. viscosa is contrary to the results of Jane et al., (2012), Siddiqui et al., (2009) and Koche et al., (2010). This variation may be associated to agro-ecological conditions, varieties, extraction methods and solvents used. Similar results were obtained by Adjatin et al., (2013) on the leaves of $C$. crepidioides and $C$. rubens indicating the absence of saponins unlike those of Arawande et al., (2013) and Gbadamosi et al., (2012 ) who found saponins in the leaves of $C$. crepidioides and $C$. rubens. The author explained the differences by the fact that the study was conducted in Beninwith aqueous solvent, while the other two were conducted in different parts of Nigeria with other solvents.

The determination of chemical compounds in the leaves powder of the two species showed the presence of tannins, flavonoids, anthocyanin, leucoanthocyanin, steroids, mucilage of reducing compounds and quinone derivatives. Hydrolysable tannins present in many plant foods were identified as being responsible in large doses, of the reduction of growth rate and protein digestibility in laboratory animals. The incidence of certain cancers including esophageal cancer is related to the consumption of foods rich in tannins (Shils et al., 2006). However the consumption of $C$. gynandra with the presence of this antinutritional compound could be explained by the fact that it is triturated before preparation and the dose is reduced.

Some authors have indicated that the low concentration of a vegetable tannin is associated with positive effects on digestion (Guimarães-Beelen et al., 2006; Emebu and Anyika, 2011). Quinone derivatives have irritant laxatives or drastic effects on the intestines causing contractions of the intestinal walls (Cowan, 1999). Mucilage have laxative properties, anti-inflammatory, anti-diarrhea and decreases the sensation of pain (Lin et al., 2005).The flavonoids (flavones) are particularly active in maintaining good blood flow (Park et al., 2008) and have a high antioxidant or anti- radical, anti-proliferative and anti-carcinogenic potential and can inhibit the growth of prostate tumors (Tomofuji et al., 2009;. Jane et al., 2012). As for anthocyanins, they slow down the aging of cells, including skin cells by improving the elasticity and skin density (Afaq et al., 2005). This corroborates 
with consideration given to $C$. gynandra by the population as "plant giving life." The strong presence of these compounds in both the leaves of $C$. gynandra and $C$. viscosa bring benefits to the body because they have antioxidant properties. The alkaloids are phytochemicals most effective in therapeutic uses (Ayoola and Adeyeye, 2010; Okwu, 2005).Our results revealed that only the leaves of $C$. gynandra contain alkaloids. These results partly confirmed those of Jane et al., (2012) and Koche et al., (2010) who reported the presence of flavonoids and tannins in the leaves of $C$. viscosa but contrasted those specifying the presence of alkaloids in $C$. viscosa.

Similarly Siddiqui et al., (2009) revealed the presence of alkaloids and tannins but the lack of flavonoids in the leaves of $C$. viscosa. This absence could be explained by high pollution in the area where sample were collected. Similarly, Mamadou (2011) in Malinoted on Nauclealati folia a high presence of alkaloids in the leaves and fruits of Kanadjiguila, Lafiabougou and Lassa sites and a very low presence of these molecules on the organs of the same species at Koulouba site. According to the author this low presence of alkaloids in Koulouba site could be explained by the exposure of the area to a high degree of pollution. Indeed, the alkaloids may be very sensitive to the presence of certain exhaust gas as source of pollution (Mamadou, 2011). Alkaloids also have anti-malarial, antimicrobial and analgesic activity, which could justify the prescription of crushed leaves or decoction of $C$. gynandra to cure jaundice and other infection. The presence of reducing compounds was confirmed by the work of Sievanesan et al., (2007) showing that the aqueous extract of $C$. gynandra has a net modulatory effect on glucose metabolism in liver cancer cells.

Many phytochemical studies have shown that leafy vegetables with medicinal properties used for various therapeutic purposes contain important phytochemical compounds (Okwu et al., 2006; Adinortey et al., 2012; Gbadamosi al. 2012; Dougnon et al., 2012; Agbaire et al., 2013; Arawande et al 2013;. Ondo et al., 2013; Adjatin et al., 2013).Because of the pharmacological properties of these various chemical compounds found in these plants, their regular consumption would help prevent or cure various diseases (Adjatin et al., 2013). This is consistent with the perception of the population on the nutraceuticals utilities of these two species (Adjatin et al., 2012).

Table.1 List, Administrative Localization and Ethnic Groups of the Villages Surveyed

\begin{tabular}{lllll}
\hline $\mathbf{N}^{\circ}$ & Villages & Districts & Department & Ethnic group \\
\hline 1 & Adromè-kpovidji & Houéyogbé & Mono & Sahouè \\
2 & Ahouamè & Lokossa & Mono & Cotafon \\
3 & Ahouango & Kpomassè & Atlantique & Aïzo \\
4 & Houéyiho & Cotonou & Littoral & Fon \\
5 & Issaba & Pobè & Plateau & Holly \\
6 & Koutongbé & Porto Novo & Ouémé & Goun \\
7 & Niaouli2 & Allada & Atlantique & Aïzo \\
8 & Okébodé & Ketou & Plateau & Nagot \\
9 & Zohoudji & Aplahoué & Couffo & Adja \\
\hline
\end{tabular}


Figure.1 Map of Southern Benin Showing Surveyed Localities

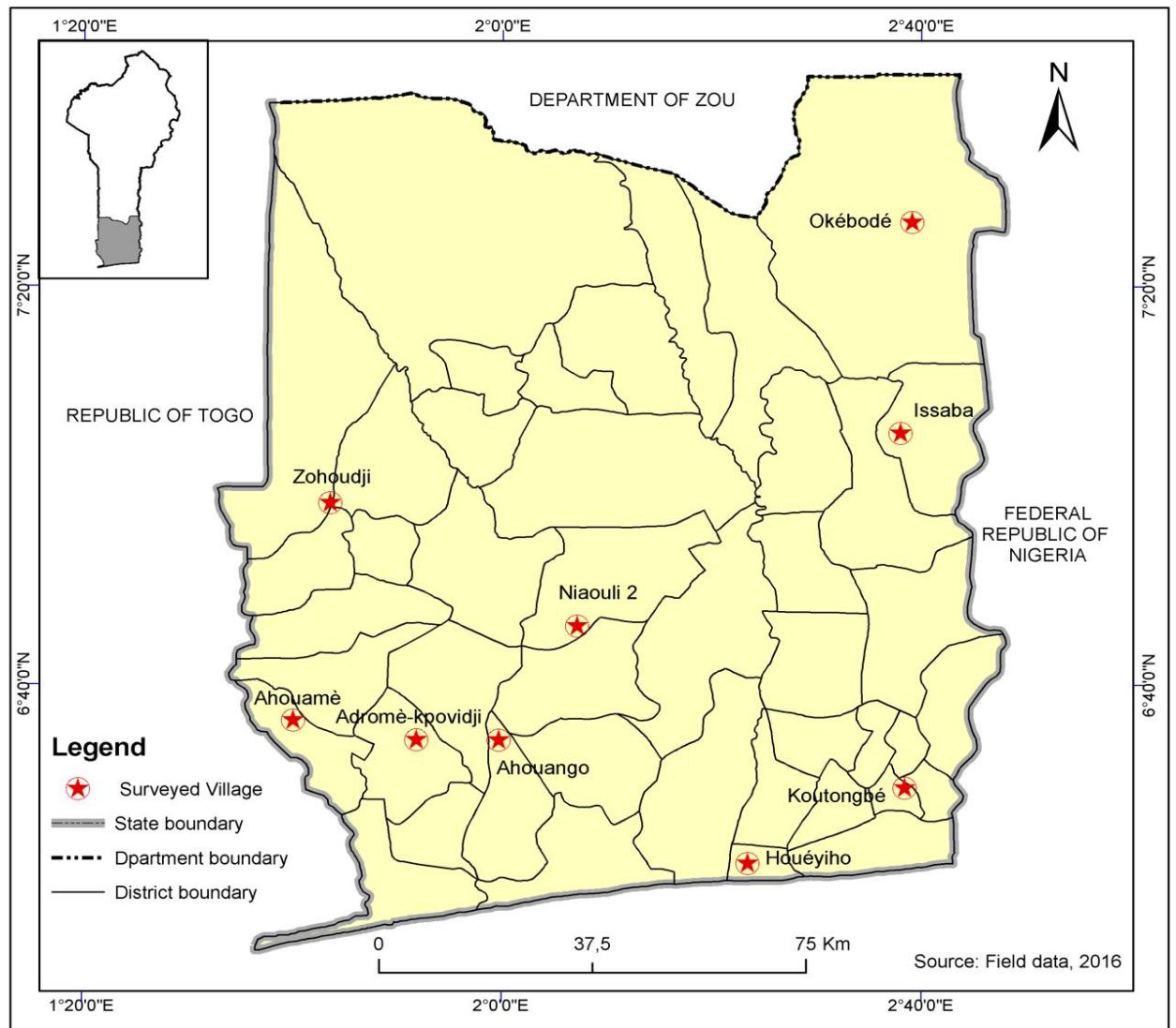

Table.2 Correspondence between Lc50 and Toxicity

\begin{tabular}{ll}
\hline LC50 & Toxicity \\
\hline $\mathrm{LC} 50 \geq 0.1 \mathrm{mg} / \mathrm{ml}$ & $-\quad$ (Non-toxic) \\
$0.1 \mathrm{mg} / \mathrm{ml}>\mathrm{LC} 50 \geq 0.050 \mathrm{mg} / \mathrm{ml}$ & + (Lowtoxicity) \\
$0.050 \mathrm{mg} / \mathrm{ml}>\mathrm{LC} 50 \geq 0.01 \mathrm{mg} / \mathrm{ml}$ & ++ (Moderate toxicity) \\
$\mathrm{LC} 50<0.01 \mathrm{mg} / \mathrm{ml}$ & +++ (Hightoxicity) \\
\hline
\end{tabular}

Table.3 Cultural Importance Index (Ci) of the Two Cleome Species in Southern Benin

\begin{tabular}{lllllllll}
\hline Species & Number & $\Sigma \mathrm{UR}_{\mathrm{UA}}$ & $\mathrm{CI}_{\mathrm{UA}}$ & $\Sigma \mathrm{UR}_{\mathrm{UM}}$ & $\mathrm{CI}_{\mathrm{UM}}$ & $\Sigma \mathrm{UR}_{\mathrm{UMM}}$ & $\mathrm{CI}_{\mathrm{UMM}}$ & $\mathrm{CI}$ \\
\hline C.gynandra & 260 & 181 & 0,70 & 98 & 0,38 & 16 & 0,06 & 1,14 \\
C.viscosa & 260 & 4 & 0,02 & 118 & 0,45 & 10 & 0,04 & 0,51 \\
\hline
\end{tabular}

Legend: $U A=$ food use, $U M M=$ medicinal use, $U M M=$ medico-magic use $; C I=$ cultural index 
Table.4 Vernacular Names of C. gynandra and C.viscosa According to the Ethnic Groups

\begin{tabular}{lll}
\hline Ethnic & \multicolumn{2}{c}{ vernacular names } \\
\cline { 2 - 3 } groups & Cleome gynandra & Cleome viscosa \\
\hline Adja & Sabo assi & Sabo assou ; Bomèsabo \\
Sahouè & Akayaassi & Akaya-assou, klouto kaya \\
Mina & Samboési & Samboésou \\
Goun & Akayaassi ; Gbodokaya & Kondo \\
Fon & Akayaassi & Hêdoulinfiman, Akayaassou \\
Cotafon & Akayaassi & Akayaassou ou Gbétokaya \\
Nago & Ewééti ; Efookpoya & Dantcha ; Ewouééyou ; Eyofa \\
Holly & Efooko & Orokoton \\
Aïzo & Akayaassi & Akayaassou \\
\hline
\end{tabular}

Table.5 Medicinal importance of C.gynandra and C.viscosa in the Study Area

\begin{tabular}{|l|l|c|c|l|}
\hline \multirow{2}{*}{$\mathbf{N}^{\circ}$} & \multirow{2}{*}{ Listed Diseases } & \multicolumn{2}{|c|}{ Species } & \multirow{2}{*}{ Organs used } \\
\cline { 3 - 4 } & & C. gynandra & C. viscosa & \\
\hline $\mathbf{1}$ & Abscesses and wound & + & + & Leaf \\
\hline $\mathbf{2}$ & Anemia & + & - & Leaves \\
\hline $\mathbf{3}$ & Bleeding after childbirth & - & + & Leaf, stem, fruit \\
\hline $\mathbf{4}$ & Candida & - & + & Leaf \\
\hline $\mathbf{5}$ & Cold & - & + & Leaf \\
\hline $\mathbf{6}$ & Difficult delivery & - & + & Leaf, stem, fruit \\
\hline $\mathbf{7}$ & dizziness & + & - & Leaf \\
\hline $\mathbf{8}$ & Earaches & + & + & Leaf \\
\hline $\mathbf{9}$ & Fever & - & + & Leaf, stem, fruit \\
\hline $\mathbf{1 0}$ & Fragilityof babies & - & + & Leaf, stem, fruit \\
\hline $\mathbf{1 1}$ & Haemorrhoid & - & + & Leaf, stem, fruit \\
\hline $\mathbf{1 2}$ & Headache & + & + & Leaf \\
\hline $\mathbf{1 3}$ & Hernia & + & - & Leaf \\
\hline $\mathbf{1 4}$ & Infection & + & + & Root \\
\hline $\mathbf{1 5}$ & Jaundice & + & - & Leaf \\
\hline $\mathbf{1 6}$ & Malaria & + & + & Leaf \\
\hline $\mathbf{1 7}$ & Sexual weakness & + & - & Leaf \\
\hline $\mathbf{1 8}$ & Tooth sores & - & + & Root \\
\hline $\mathbf{1 9}$ & Ulcer & - & - & Leaf, stem, fruit \\
\hline $\mathbf{2 0}$ & Vomiting & - & + & Leaf \\
\hline
\end{tabular}

Table.6 Correlation between Variables and the Main Factors

\begin{tabular}{lcccc}
\hline Variables & \multicolumn{2}{c}{ C. gynandra } & \multicolumn{2}{c}{ C. viscosa } \\
\cline { 2 - 5 } & Factor 1 & Factor 2 & Factor 1 & Factor 2 \\
\hline Food use (UA) & 0.65 & 0.74 & 0.66 & -0.45 \\
Medicinal use (UM) & 0.73 & -0.40 & 0.52 & 0.83 \\
Medico-magical use (UMM) & 0.75 & -0.24 & -0.71 & 0.18 \\
\hline
\end{tabular}


Table.7 Organic Compounds Identified in the Two Species Studied

\begin{tabular}{lcc}
\hline Compounds & C. gynandra & C. viscosa \\
\hline Alkaloïd & ++ & - \\
Catechin tannins & + & ++ \\
Gallic tannins & + & + \\
Flavonoids & ++ & + \\
Anthocyanin & + & ++ \\
Leuco-anthocyanins & - & ++ \\
Saponins & - & - \\
Triterpenoids & + & - \\
Steroids & - & + \\
Cardenolides & - & - \\
Cyanogenic derivatives & ++ & + \\
Mucilages & - & - \\
Coumarins & ++ & ++ \\
Reducing compounds & - & - \\
Free anthracene & - & - \\
Anthracene combined to O-heterosides & ++ & + \\
Anthracene combined to C-heterosides & + & ++ \\
Quinone derivatives & &
\end{tabular}

NB : + : present ; ++ : abondant ; - : absent

Figure.2 Level of Domestication of C.viscosa in the Villages Surveyed

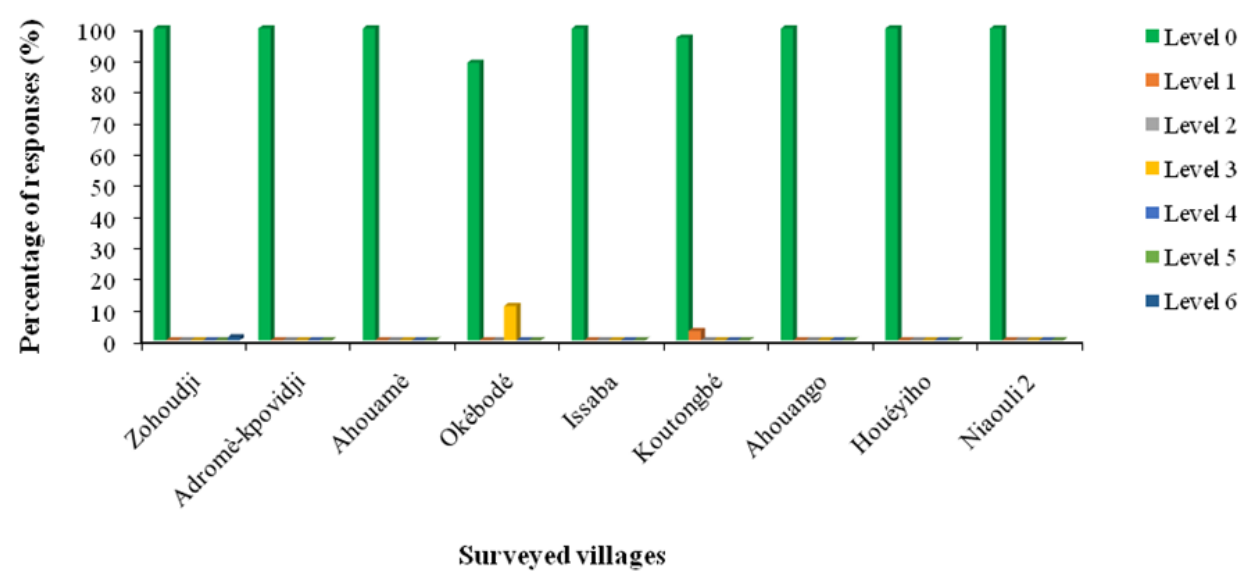


Figure.3 Level of Domestication of C.gynandra in the Villages Surveyed

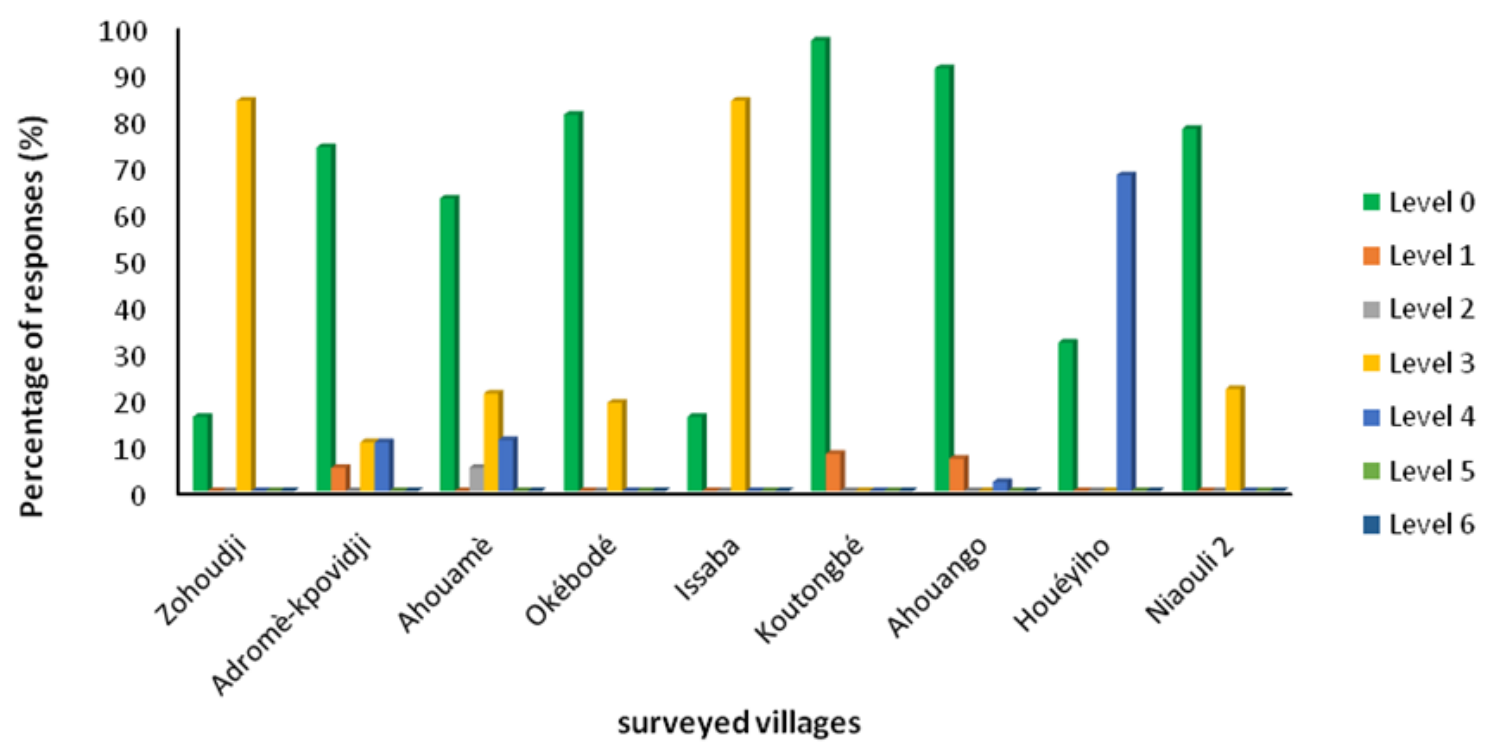

Figure.4 Representation of Ethnic Groups in the Plan Defined by the First Two Major Components with $C$. gynandra

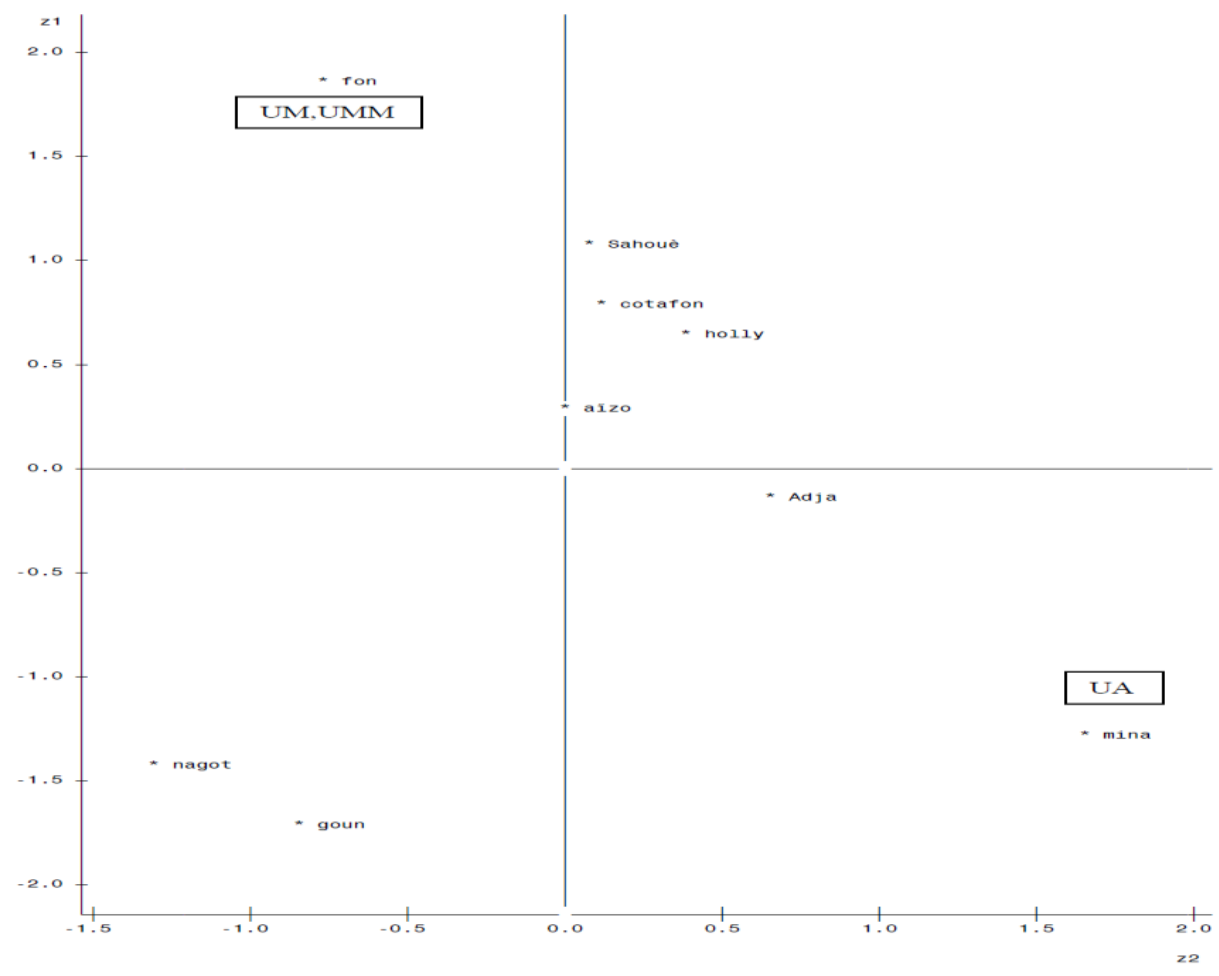


Figure.5 Representation of the Ethnic Groups in the Plan Defined by the First Two Major Components with $C$. viscosa

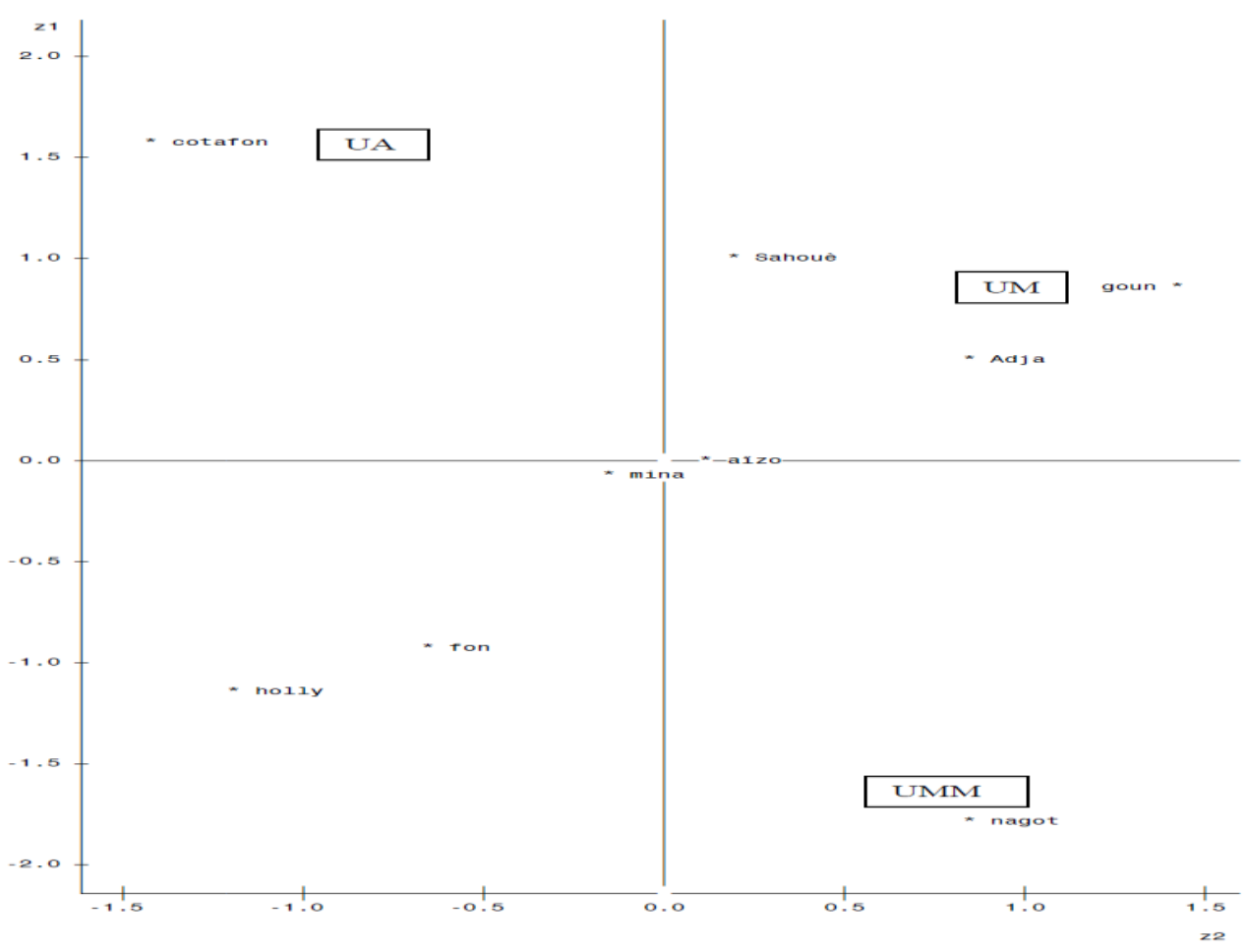

Figure.6 Toxicity Curve of Leaves Extract of C.gynandra on Shrimp Larvaes

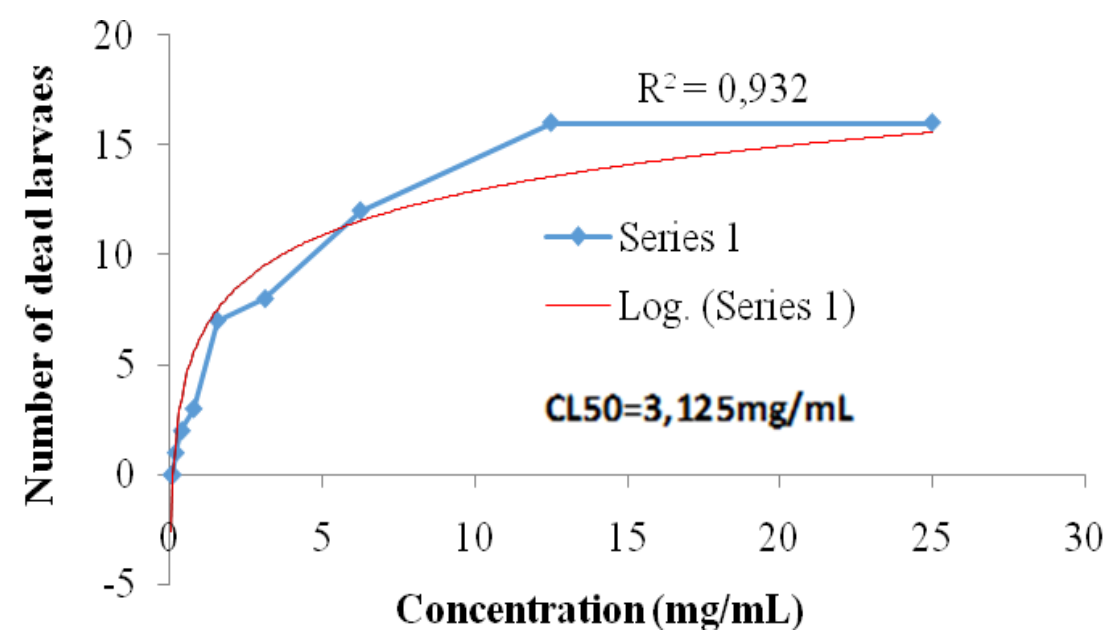




\section{Figure.7 Toxicity Curve of Leaves Extract of C.viscosa on Shrimp Larvaes}

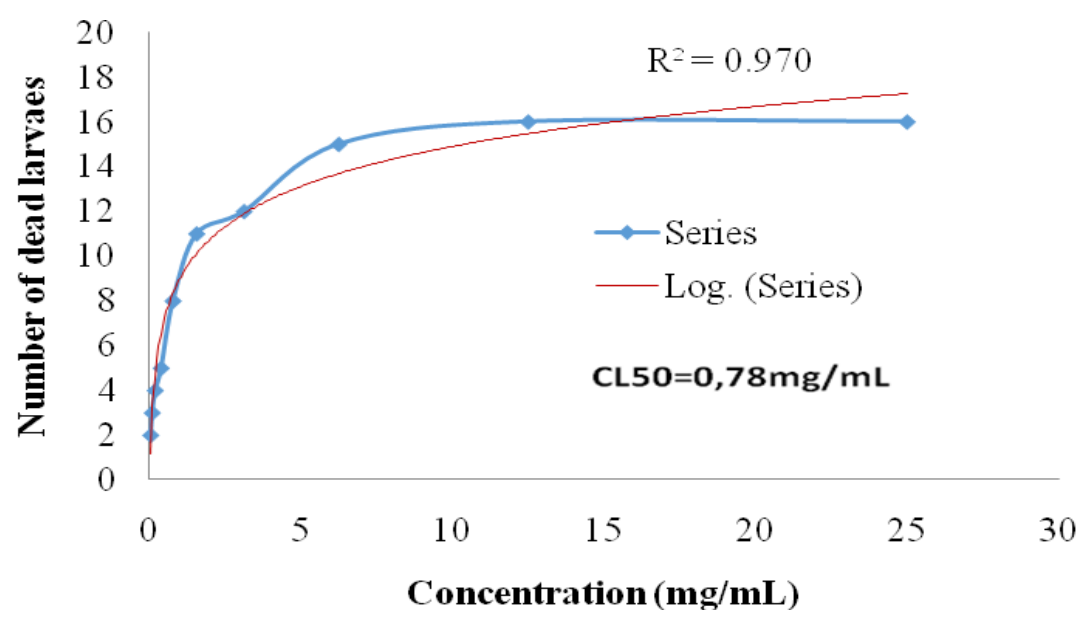

Toxicity of C. gynandra and C. viscosa

The analysis of the sensitivity curves of the figures 6 and 7 shows that the shrimp larvae are susceptible to extracts tested according to the dose-response relationship. Indeed progressively as the aqueous concentration of the leavesof each species increases, the number of dead larvae increases. But this increase is faster with C.viscosa aqueous extract than the one of $C$. gynandra. In addition the concentration of 50\% (LC50) survival of shrimp larvae is $3.125 \mathrm{mg} / \mathrm{ml}$ for C. gynandra and $0.78 \mathrm{mg} / \mathrm{ml}$ for C.viscosa.

Shrimp larvae (Artemiasalina) were sensitive to aqueous extracts of the leaves of $C$. gynandra and $C$. viscosa indicating that the samples are biologically active with a limit dose of mortality equal to $0.78 \mathrm{mg} / \mathrm{ml}$ for $C$. viscosa and 3,125mg / $\mathrm{mL}$ for C. gynandra. The sensitivity curves showed that the larval mortality increases with the concentration. This sensitivity thus follows a dose-response relationship. Furthermore, the values of the lethal dose $($ LC50 $=0.78 \mathrm{mg} / \mathrm{ml}$ for the leaves of C. viscosa and $3,125 \mathrm{mg} / \mathrm{ml}$ for leaves of $C$. gynandra) are all greater than 0.1 $\mathrm{mg} / \mathrm{ml}$ which is the limit dose of toxicity according to Mousseux (1995). These results reveal that none of the two species is toxic.
This is similar to the work of Karimulla $e t a l$., (2013) which revealed the absence of toxicity sign of C. gynandra on rats at a dose of $2000 \mathrm{mg} / \mathrm{kg}$. Similarly, Elufioye et al., (2015) showed the non-toxicity of $C$. viscosa on mice because no animal died during 24 hours after oral administration of the extract and the LC50 was greater than $5000 \mathrm{mg} / \mathrm{kg}$. These signs are confirmed by Deora et al., (2010) who reported that that the lethal dose is greater than $5000 \mathrm{mg} / \mathrm{kg}$. This corroborates with our survey results revealing the food use of $C$. viscosa without a major risk of poisoning.

In conclusion, this ethnobotanical, phytochemical assessment and the risk of toxicity study on $C$. gynandra and $C$. viscose is a starting point of a vast program of domestication of the two species. C. gynandra is more used for food while C. viscosa is more used for traditional medicine. The qualitative phytochemical screening of $C$. gynandra and C. viscosa revealed the presence of many chemical compounds that justified their medicinal values. The toxicity study revealed that none of the species is toxic and can therefore be consumed without risk. $C$. gynandra and $C$. viscose are two nutraceuticals leafy vegetables that must be promoted through domestication and development of food based products. 


\section{References}

Adam S., Boko M., (1993). Le Bénin. Les éditions du Flamboyant / EDICEF

Adinortey M.B., Sarfo J.K., Quayson E.T.,Weremfo A., Adinortey C.A., Ekloh W., Ocran J., (2012). Phytochemical screening, proximate and mineral composition of Launeaetaraxacifolialeaves. Research Journal of Medicinal 6 (2): 171-183.

Adjatin A., Dansi A., Badoussi E., Loko Y. L., Dansi M., Azokpota P., Gbaguidi F., Ahissou H., Akoègninou A., Akpagana K., Sanni A., (2013).Phytochemical screening and toxicity studies of Crassocephalum rubens(Juss. ex Jacq.) S. Moore and Crassocephalum crepidioides (Benth.) $\mathrm{S}$. Mooreconsumed as vegetable in Benin. Int. J. Curr. Microbiol. App. Sci: 2(8): 1-13

Adjatin A., Dansi A., Eze C. S., Assogba P., Dossou-Aminon I., Akpagana K., Akoegninou A., Sanni A., (2012). Ethnobotanical investigation and diversity of Gbolo(Crassocephalum rubens(Juss. ex Jacq.) S. Moore and Crassocephalum crepidioides (Benth.)

S. Moore), a traditional leafy vegetable under domestication in Benin

Agbaire P.O., Emudainohwo J.O.T, Peretiemo-Clarke B. O.(2013).Phytochemical screening and toxicity studies on the leaves of Manniophytonfulvum.International Journal of Plant, Animal and Environmental Sciences, 3 (1) : 1-6.

Ajaiyeoba, E. O., (2000). Phytochemical and antimicrobial studies of Gynandropsis gynandra and buchholziacoriaceae extracts. Afr. J. Biomed. Vol 3: 161 165

Akoegninou, A., Van der Burg, W.J., Van der Maesen, L.J.O., Adjakidjè, V., Essou, J.P., Sinsin, B., Yédomonhan,
H., (2006). FloreAnalytique du Benin. Backhuys Publishers, Leiden, The Netherlands.

Arawande J.O., Komolafe E.A., Imokhuede B., (2013). Nutritional and phytochemical compositions of fireweed (Crassocephalum crepidioides). International Journal of Agricultural Technology, 9 (2): 371381.

Ayoola P.B., Adeyeye., (2010). Phytochemical and nutrient evaluation of Carica papaya (pawpaw) leaves. IJRRAS, 5(3): 325-328.

Codjia J. T. C., Vihotogbe R., Lougbegnon T.O., (2009). Phytodiversité des légumes-feuilles locales consommées par les peuples Holli et Nago de la région de Pobè au sud-est du Bénin Int. J. Biol. Chem. Sci. 3(6): 12651273

Dansi A., Vodouhè R., Azokpota P., Yedomonhan H., Assogba P., Adjatin A., Loko Y.L., Dossou-Aminon I., Akpagana K. (2012). Diversity of the Neglected and Underutilized Crop species of importance in Benin.Sci. World J., 1-19. DOI 10.1100/2012/932947.

Deora P.S., Mishra C.K., Mavani P., Asha R., Shrivaatava B., RajeshK.N., (2010). Effective alternative methods of LD50 help save numbers of experimental animal.J.Chem Pharm Res. 2(6): 450-453

Djègo J., Djego-djossou S., Cakpo Y., Agnani P. and Sinsin B., (2011). Evaluation $\mathrm{du}$ potentiel ethnobotanique des populations rurales au Sud et au centre du Bénin. Int. J. Biol. Chem. Sci. 5(4): 1432-1447

Dougnon T.V., Bankolé H.S., Johnson R.S., Klotoé J.R., Fernand G.D., Assogba G.F., (2012). Phytochemical Screening, Nutritional and Toxicological Analyses of Leaves and 
Fruits of Solanummacrocarpon Linn (Solanaceae) in Cotonou (Benin).Food Nutr. Sci., 3: 1595-1603.

Emebu P.K., Anyika J.U., (2011). Vitamin and antinutrient composition of kale (Brassica oleracea) grown in Delta State, Nigeria. Pakistan Journal of Nutrition, 10(1): 76-79.

Gbadamosi I.T., Sulaiman M.O., (2012). In vitro Growth and Shoot Production of Seeds of Crassocephalum rubens(Juss. Ex Jacq.) S. Moore (Asteraceae). World Journal of Agricultural Sciences 8 (2): 193-197

Guimarães-Beelen P.M., Berchielli T.T., Beelen R., Filho J.A., de Oliveira S.G., (2006). Characterization of condensed tannins from native legumes of the Brazilian northeastern semi-arid. Scientia Agricola, 63(6): 522-528.

Koche, D., Shirsat, R., Syed, I. and Bhadange, D. G., (2010). Phytochemical screening of eight traditionally used ethanomedicinal plants from Akola district (MS), India. Int. J. Pharm. Bio. Sci. 1, 253-256.

Koura, K., Ganglo, J. C., Assogbadjo, A. E., Agbangla, C., (2011). Ethnic differences in use values and use patterns of Parkiabiglobosa in Northern Benin. Journal of Ethnobiology and Ethnomedicine, /7/1/42.

Lin S.Y., Liu H.Y., Lu Y.L. Hou W.C. (2005). Antioxidant Activities of Mucilages from different taiwaneseyam cultivars. Botanical Bulletin of Academia Sinica, 46: 183188.

Mishra S.S, Moharana S.K, Dash M.R., (2011). Review on Cleome gynandra. International journal of research in pharmacy and chemistry, 1(3) .ISSN: 2231-2781

Okwu D.E., (2004). Phytochemical and vitamin content of indigenous species of South Eastern Nigeria. Journal of Sustainable Agriculture and Environmental, 6.30-37.

Okwu D.E., (2005). Phytochemicals, vitamins and mineral contents of two Nigeria medicinal plants. Inter. Journal of Molecular Medecine an advance Sciences, 1(4): 375-381.

Ondo J. P., Obame L.C., Akoue G.N., Engono J.P.M., Parkouda S., Emvo E. N., Lebibi J., (2013). Studies on phytochemical screening, total phenolic content and antiradical activityofthree extracts ofEmiliasagittata DC. (Asteraceae). International Journal of Biosciences, 3(4): 50-57

Park HH., Lee S., Son HY., Park SB., Kim MS., Choi EJ., Singh TS., Ha JH., Lee MG., Kim JE., Hyun MC., Kwon TK., Kim YH., Kim SH., (2008). Flavonoids inhibit histamine release and expression of proinflammatory cytokines in mast cells. Arch. Pharm. Res., 31(10): 1303-1311.

Siddiqui, S., Verma, A., Rather, A. A., Jabeen, F. and Meghvansi, M. K., (2009). Preliminary phytochemicals analysis of some important medicinal and aromatic plants.Advan. Biol. Res. 3, 188-195.

Sivanesan D., Hazeena Begum V., (2007). Modulatory effect of Gynandropsis gynandra L. on glucose metabolizing enzymes in aflatoxin B1-induced hepatocellular carcinoma in rats. Indian journal of biochemistry and biophysics vol. 44, December 2007, pp. 447-480

Soro L. C., Ocho-aninAtchibri A. L., Kouadio K.K.A., Kouamé C., (2012). Evaluation de la composition nutritionnelle des légumes feuilles. Journal of Applied Biosciences 51: 3567- 3573 Issn 1997-5902 
Tardío J et Pardo-de-santayana M.,(2008). Cultural Importance Indices: A Comparative AnalysisBased on the Useful Wild Plants of Southern Cantabria (Northern Spain). Economic Botany, 62(1), 2008, pp. 24-39

Tomofuji T., Ekuni D., Irie K., Azuma T., Endo Y., Tamaki N., Sanbe T., Murakami J., Yamamoto T., Morita M. (2009). Preventive effects of a cocoa-enriched diet on gingival oxidative stress in experimental periodontitis. J. Periodontol., 80 (11): 1799-1808.

Visweswari, G., Christopher, R. and Rajendra, W., (2013). "Phytochemical screening of active secondary

metabolites present in Withaniasomnifera root: role in traditional medicine". International Journal of Pharmaceutical Sciences \& Research, 4(7). 2770.

Vodouhè R., Dansi A., (2012). The "Bringing into Cultivation" Phase of the Plant Domestication Process and Its Contributions to In Situ Conservation of Genetic Resources in Benin. The ScientificWorld Journal, doi:10.1100/2012/176939; 1-13.

Zwenger S, Basu C., (2008). Plant terpenoids: applications and potentials. Biotechnology and Molecular Biology Reviews; 3:001-007.

\section{How to cite this article:}

Ahouansinkpo, E., J. Atanasso, A. Dansi, A. Adjatin, Orobiyi Azize and Sanni, A. 2016. Ethnobotany, Phytochemical Screening and Toxicity Risk of Cleome gynandra and Cleome viscosa, two traditional leafy vegetables consumed in Benin. Int.J.Curr.Microbiol.App.Sci. 5(2): 813-829. doi: http://dx.doi.org/10.20546/ijcmas.2016.502.093 